\title{
Reviewing Effluent and Estuarine Water Quality in View of Introducing Effluent Standards for Coastal Aquaculture in Sri Lanka
}

\author{
A.S.L.E. Corea \\ National Aquatic Resources Research and Development Agency, Crow Island, \\ Colombo 15, SRI LANKA \\ Corresponding Author: \\ E-mail: scorea@nara.ac.lk
}

\begin{abstract}
Coastal aquaculture commenced in the 1980 's in Sri Lanka with the shrimp farming industry. The major coastal aquaculture activity even at present is shrimp culture. However, it has caused pollution in the coastal areas due to its untreated effluents being discharged to coastal water bodies. Although effluent treatment prior to release is recommended, it is not practiced. The pollution caused by the industry has not only affected the other aquatic organisms, but has affected the industry itself through disease spread.

Many countries in the world have recognized shrimp culture as a highly polluting industry, and are taking measures to control pollution. Therefore, it is time that Sri Lanka also introduced methods to control coastal area pollution from aquaculture effluents. The present paper reviews the available water quality in the estuarine systems, and the effluent quality discharged from farms to suggest standards for the aquaculture effluents with a view of reducing the pollution to coastal areas.
\end{abstract}

Key words: Aquaculture Effluent quality, Effluent limits, Effluent standards

\section{Introduction}

The coastal pollution caused by the shrimp culture industry is a threat to the coastal aquatic diversity as well as to the sustainability of the industry. ( Corea et al 1998, Phillips 1995)This has been recognized in most parts of the world and mitigation methods have been introduced. In Sri Lanka farm approval was granted with a regulation that the effluents need to be treated prior to release. But since there is no monitoring mechanism, this regulation has been violated since the beginning of the 
industry. Presently many countries are introducing standard levels for the effluent quality to be released to the environment. The idea of introducing standards occurred in the early 1990's in Sri Lanka but it never materialized. (CEA 1990)

Since the 1990's several studies have been done on shrimp farm effluents and treatment methods. (Suresh Kumar et al 1993, Corea et al 1995, Jayasinghe1998) These methods have been introduced to the farmers as well, although it has not been adopted. The present paper reviews the condition in the estuarine system in the shrimp farming areas and the changes that have occurred, as well as the quality of effluents with and without adoption of better management practices.

The objective of this paper is to introduce standard levels for aquaculture effluents released to the coastal water bodies, considering the treatment methods available as well as the standard levels set in other countries to manage the aquaculture effluents. This would help to reduce the pressure on the coastal water bodies and protect the organisms living in them including the commercially important species.

\section{Water quality in the Estuarine system}

The Mundel - Puttalam estuarine system connected by the Dutch canal was a water way used for transport purposes originally and later abandoned. The system therefore was neglected and only used by the local fishers for fishery activity. Some other local industries such as the coir industry used the canal water. The water movement in the canal was restricted due to sand bar formation blocking its connections with the sea. (Wijeratne et al. 1996) Since these sand bars prevented water exchange with the sea, the water that came in from the fresh water rivulets fed the system and was responsible for the limited water movement in the canal and its water quality. Therefore, the water quality changed seasonally with increased salinity during the dry seasons and reduced salinity during rainy periods. The water quality in different parts of the system varied according to the quantity of water received by the system, and other anthropogenic activities. In areas where coir industry was practiced, the $\mathrm{pH}$ levels were lower than the other areas. However, the water quality was not within acceptable levels for aquaculture in all parts of the system even during the period, when shrimp culture was introduced to the area in late 1980's. (NARA 1987) The estuarine system itself was in a neglected state, as it was no longer used for navigation and the major activity was the lagoon fishery, before shrimp culture commenced.

For the purpose of finding suitable areas for shrimp culture, a survey had been carried out in 1987 and the soil and water conditions have been evaluated. (NARA 1987). Since the rapid development of shrimp culture in the early 1990's and due to different water related disease conditions observed in the shrimp industry, water quality has been monitored in selected areas of the system which support shrimp culture, at 
different intervals. Since tidal mixing is restricted by the closing of sea- mouths of the system, due to sand bar formation, water exchange in the system occurs only during heavy rains when water movements are facilitated by the fresh water inflow. (Jayasiri et al 1997) The flushing depends on the quantity of water received and the opening of sea mouths. The sea mouths are forced open when floods occur in the surrounding villages, and if they are opened before proper flushing of the system occurs, then the water may flow out through the opening without making much impact on the estuarine system itself. The water quality changes with the introduction of shrimp culture has been reflected in the various publications since then. (Corea et al 1995, 1998, 2007, Jayasinghe et al, 1994) The results summarized in Table 1 indicates a time series change in the water quality of the estuarine system as a whole. However different areas of the system show high variation in water quality, which may be a result of the climatic differences and the fresh water inflow to the different regions of the system. Especially since there is very little water movement, water quality in the areas that receive fresh water would be different from the areas that does not have any fresh water inputs.

The shrimp industry was affected by a viral epidemic in the period $1989-1991$ and its spread was related to poor quality water used for culture purposes. (ADB report 1990) Therefore using better quality water for the shrimp industry and to maintain good conditions in culture ponds became a necessity as early as 1990. Since water in the system was contaminated by the direct release of effluents, the need to treat the effluents released into the estuarine system was highlighted. However, since the disease condition was controlled by using lower stocking densities and managing the pond conditions, the industry expanded rapidly during the early 1990's. The next viral epidemic was reported in 1996, and its fast spread was attributed to poor water quality as well as the discharging of contaminated effluents into the estuarine system. Again the need for effluent treatment was highlighted as a measure to controlling disease. (Corea et al 1997) The poor water quality in the estuarine system received attention with recommendations for improvement. 
Table 1: Time series changes in water quality in the Dutch canal Mundel estuarine system

\begin{tabular}{|c|c|c|c|c|c|c|c|}
\hline Parameter & 1987 & 1992 & 1995 & 1998 & 2001 & 2007 & 2014 \\
\hline $\begin{array}{l}\text { Dissolved oxygen } \\
(\mathrm{mg} / \mathrm{l})\end{array}$ & $5.6-8.0$ & $5.4-7.2$ & $4.2-6.9$ & $4.1-5.8$ & $5.0-7.4$ & 4.6- 7.8 & $4.2-6.0$ \\
\hline $\begin{array}{l}\text { Phosphate } \\
(\mathrm{mg} / \mathrm{l})\end{array}$ & $0.02-0.3$ & $0.05-2.0$ & $0.09-3.4$ & $1.2-2.32$ & $0.08-1.85$ & $0.05-2.1$ & $0.06-1.3$ \\
\hline Nitrate $(\mathrm{mg} / \mathrm{l})$ & $0.01-1.6$ & $0.02-3.4$ & $0.04-3.76$ & $0.38-3.82$ & $0.03-3.51$ & $0.04-2.1$ & $0.2-1.8$ \\
\hline Nitrite (mg/ l) & $0.002-0.032$ & $0.02-0.96$ & $0.03-0.372$ & $0.038-0.44$ & $0.02-0.241$ & $0.009-0.13$ & $0.001-0.25$ \\
\hline $\begin{array}{l}\text { Total Ammonia } \\
(\mathrm{mg} / \mathrm{l})\end{array}$ & NA & $0.001-0.043$ & $0.016-0.084$ & $0.045-0.86$ & $0.14-0.56$ & $0.041-0.081$ & $0.01-0.2$ \\
\hline Sulphide $(\mathrm{mg} / \mathrm{l})$ & $0.02-0.5$ & $0.10-0.82$ & $0.20-0.98$ & $0.21-0.43$ & $0.18-0.86$ & $0.12-0.54$ & $0.1-0.32$ \\
\hline $\mathrm{BOD}(\mathrm{mg} / \mathrm{l})$ & NA & $10.6-28.0$ & $12.4-62.8$ & $18.2-36.76$ & $10.8-48.4$ & $10.4-28.3$ & $9.2-38.6$ \\
\hline $\begin{array}{l}\text { Total suspended } \\
\text { solids (mg/l) }\end{array}$ & $10.0-22.0$ & $20.0-140.0$ & $50.0-250.0$ & $163.3-292.0$ & $50.0-200.0$ & 53.6- 182.6 & $42.8-196.7$ \\
\hline Turbidity (NTU) & $7.0-18.0$ & $5.0-23.0$ & $11.0-87.0$ & - & $11.0-80.0$ & - & $8.0-72.0$ \\
\hline Temperature $\left({ }^{0} \mathrm{C}\right)$ & $28.0-32.0$ & $25.0-34.0$ & $25.0-34.0$ & $24.5-33.0$ & 25.033 .0 & $26.0-33.5$ & $26.0-33.5$ \\
\hline Salinity (ppt) & $0-33$ & $0-36$ & $0-38$ & $0-44$ & $0-30$ & $3-50$ & $10-52$ \\
\hline $\mathrm{pH}$ & $4.8-6.0$ & $7.2-8.5$ & $7.4-8.9$ & $7.3-9.0$ & $7.3-9.1$ & $7.4-8.9$ & $7.1-8.6$ \\
\hline
\end{tabular}


As water quality degradation and restricted water movement in the water source, was considered one major reason for spread of disease in shrimp farms, Fisheries authorities initiated a dredging plan for the estuarine system in 2001. The study recommended the deepening of some parts of the Dutch canal to facilitate better water movement and opening of some sand bars covering the sea openings of the estuarine system which would facilitate tidal mixing. (Arulananthan 2005) It also recommended the dredging of the areas of the Dutch canal completely silted by farm effluents. This could be witnessed specially in the areas close to Puttalam lagoon, where the Dutch canal is heavily silted, and some of the islands that were in the Dutch canal system originally, have now been connected to the land through the accumulated silt. Most areas in the Dutch canal is now less than $1 \mathrm{~m}$ in depth but it had been deeper during the periods the canal was used for transport. This situation has restricted the water movement in the canal limiting mixing through the small tidal changes, and even causes floods during rainy seasons. (Dayaratne et al 1998)

The water quality in the estuarine system varied according to the number of farms operated during a given time period. The water source contained poor quality water during the mid-1990's when all shrimp farms in the area were operational and water use was at a peak level. The total pond area operated during this period was around 2800ha, using water from the system, as well as discharging effluents to the system. Changes in farm operation with time, shows the increase in number of operational farm area until the White spot disease outbreak. (Figure 1)

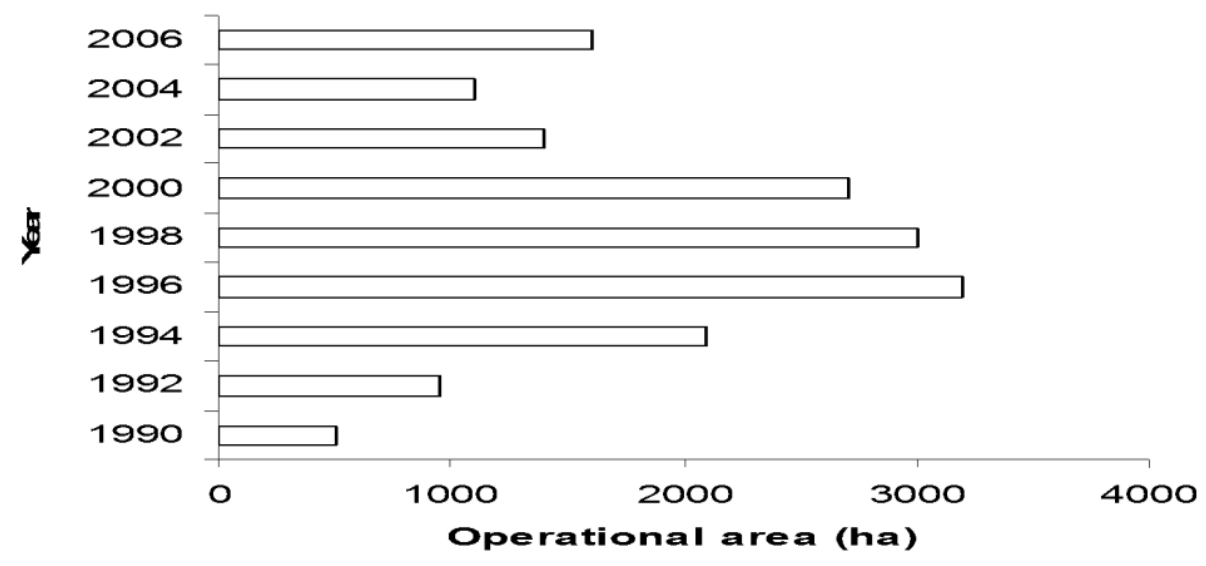

Figure 1: Time series changes in operational farm area from $1990-2006$

A gradual decline in operational farms due to disease is seen thereafter. The water use increased proportionately until the disease outbreak, when either the farms were shut down or the water changes were reduced. Regular water exchange, and release 
of untreated effluents directly to the estuarine system was observed prior to the white spot disease. Nonetheless, the accumulated effluents remained in the system, since flushing did not occur regularly and the retention time of effluents was between 150 - 260 days during the dry season. (Dayaratne et al 1998) Therefore the water quality in the system changed gradually, although the number of operational farms and the quantity of water used decreased at once after the disease outbreaks.

Table 1and Figure 1 showed a relationship between water quality in the estuarine system and increasing number of operational farms, during the early period of shrimp culture development. As the water quality deterioration in the estuarine system has occurred with the increase of farms, it is evident that discharge of untreated effluents has been responsible for the changes. But with the reduction in farm operation due to disease, there is no proportionate improvement in the water quality in the lagoon system. This may be due to the accumulated pollutants in the estuarine sediments. However, since the number of farms operated was much less by 2010 and fluctuates annually at present, the water quality has been maintained at a similar level in the estuarine system within the past few years.

After the introduction of the shrimp culture practices to the North western province, many coastal lands, specially mangroves and salt marshes bordering the estuarine system were converted for shrimp culture. The rainwater which would have been detained by these wetlands now flowed directly into the estuary and the silt and other solid particles that were washed with the rain water also found its way directly to the estuary. During the process of shrimp culture development and operation, the water body received more silt and organic particles which reduced its depth through sedimentation and the water movement has been further reduced. As some parts of the Dutch canal contains less than $20 \mathrm{~cm}$ water depth during the dry seasons and this is also continuously used for water exchange in farms, the water movement is mainly between the canal and the farms, rather than a movement from one part to the other part of the canal. (Corea 2009) This is especially true for Northern Dutch canal area from Mangalaeliya to Palavi . Therefore, tidal mixing is minimal and these substances reaching the water body will remain within the area for a long period. A study carried out in 1996 showed that the resident period of particles released to the Mundel lake was 160 days (Dayaratne et al 1998). The water movement in the southern Dutch canal area was a little different as the water movement in this part of the system varied seasonally. During rainy seasons the water moved faster than during the dry periods and in the Northern Dutch canal the direction of water movement also changed with the season, depending on the quantity of fresh water flowing into the system. (Jayasiri et al 1998)

Continuous discharges of effluents from shrimp farms, affect the water quality in the estuarine system. During heavy rains flushing of the water body is observed, which 
may occur, once or twice annually, depending on the precipitation received in the area, as well as water received from Deduru Oya and other rivers, feeding the estuarine system. But during very dry years, with very low precipitation the annual flushing may not occur at all. Since the major input of fresh water comes through Deduru oya, the water in the canal is pushed from south to North up to the Puttalam lagoon. The water fed by Sengal oya, Battulu oya etc. opening to the southern part of the Dutch canal, also is pushed in this direction. There are no fresh water inlets in the Northern part of the Dutch canal, between the Mundel lagoon and the Puttalam lagoon. But if the sand bars at Udappuwa, Muthupanthiya or Deduru oya is opened the water is drained out from these openings and the flushing of the northern parts of the Dutch canal may not occur. Often the water is drawn from North to south (Puttalam lagoon to Mundel area) if, the sand bars in the southern areas are opened, and this water movement is not sufficient to flush any accumulated sediments. Therefore, the sediments in the Northern Dutch canal remains while the water level also may not increase in this area, due to drainage through the southern sea openings. Nevertheless, the effluents released to the water body play a major part in the water quality and sediments of the estuarine system as it feeds most of the nutrients, metabolic wastes of shrimp and sediment particles into the system. The estuarine system is used for fishery activities at present and has a commercial fishery continuing from times before commencement of shrimp farming activities. It is also the major livelihood activity of some locals in the area. (Dayaratne et al 1997) according to fishers, presently the fishery production is affected by the deteriorating water quality.

\section{Effluent quality}

Shrimp culture effluents contain high loadings of nutrients as well as organic matter. Since the culture ponds are fertilized to maintain algae and through accumulation of excess feed and faecal matter, shrimp effluents contain high levels of suspended solid particles too. The effluents have been directed to the estuarine system without allowing sedimentation and all these particles settle within the estuarine system, where the water is stagnated for a long period, this causes the silting of the lagoon, accumulation of organic matter and nutrients in the lagoon, resulting in eutrophication and sometimes formation of toxic algal blooms. (Corea et al 1993)

The effluent quality changes with the farming practices adopted. During the past, when extensive, semi-intensive and intensive farming practices were operated, the effluent quality from different farming practices contained different concentrations of nutrients and suspended particles. (Sureshkumar 1998) However at present, as a measure to control disease, all farms are supposed to operate at semi-intensive level, the variation between the levels of nutrients and suspended particles is less between 
farms. Yet, since different farms use different probiotics and water treatment systems, and different feeds, some variation among the effluent quality is observed. (Corea et al 2002) The effluent quality is also directly affected by rains and drought, which affects the water exchange rates.

Presently the water exchange is limited and is carried out only when essential, while in the past it was carried out on a regular basis at intervals of 1, 23 or 7 days, commencing after the 1 st month of the culture cycle. Now the commencement of water exchange may even be later than 1 month as a measure to reduce the risk of disease spread through water. However, this does not seem to have a direct impact on the effluent loadings, as the amount of nutrients and suspended particles released, in weekly or prolonged water exchange could be higher than released during regular water exchange. The general quality of the effluents is given in Table 2 . This table compares the effluent quality during 4 different periods. In 1995 farming was at a peak level with high operational area and regular water exchange; while in 2000, farm operation was reduced but heavy use of chemicals, growth enhancers and immuneenhancers, to control disease and increase growth of shrimp to a marketable size, in the shortest possible period was practiced. However, water changes were lesser than the earlier period. By 2007 water exchange had further reduced but use of different chemicals, immune enhancers and growth enhancers also had reduced. The most commonly used method for water quality control within ponds was through probiotics. (Corea 2007) Even the amount of lime and fertilizer used in pond preparation has been reduced compared to the early years of shrimp culture. By 2014 most farmers treated the incoming water at least by using a filter net. Many used chlorine or other chemical applications prior to stocking. Use of probiotics etc. had increased for water quality control. Therefore, the water used in the culture ponds were of better quality than the water in the estuarine system. However, water exchange was limited as a precaution to disease emergence and water was kept in the pond for the maximum possible time. Therefore, the effluents did not show much improvement and still it was released directly to the environment, even though they had been advised to use sedimentation prior to release. Since the numbers of operational farms are on the rise again, the impact of effluents released directly to the environment has started creating many problems to the natural fauna in the estuarine system again, specially the commercially important fish species. Mortality of fish near effluent discharge points have been observed by fisher folk. 
Table 2: The general quality of the effluents

\begin{tabular}{|c|c|c|c|c|}
\hline Parameter & 1995 & 2000 & 2007 & 2014 \\
\hline Temperature $\left({ }^{\circ} \mathrm{C}\right)$ & $26.0-34.0$ & $26.0-31.0$ & $27.0-34.0$ & $27.5-33.0$ \\
\hline Salinity (ppt) & $07-50$ & $05-38$ & $08-40$ & $18-42$ \\
\hline Turbidity (NTU) & $16-64$ & $18-89$ & $22-92$ & $26-103$ \\
\hline $\begin{array}{l}\text { Dissolved } \\
\text { Oxygen (mg/l) }\end{array}$ & $4.2-5.4$ & 4.4- 5.7 & $4.0-5.1$ & $3.6-5.2$ \\
\hline $\mathrm{pH}$ & $7.6-9.2$ & $7.9-8.8$ & $7.8-9.0$ & $7.7-8.8$ \\
\hline $\begin{array}{l}\text { Total Ammonia } \\
(\mathrm{mg} / \mathrm{l})\end{array}$ & $0.025-0.13$ & $0.028-0.16$ & $0.036-0.15$ & $0.021-0.2$ \\
\hline Nitrate (mg/l) & $0.13-0.45$ & $0.072-0.28$ & $0.006-0.32$ & $0.01-0.28$ \\
\hline Nitrite (mg/l) & $0.026-0.016$ & $0.027-0.05$ & $0.008-0.049$ & $0.003-0.026$ \\
\hline $\begin{array}{l}\text { Phosphate } \\
(\mathrm{mg} / \mathrm{l})\end{array}$ & $0.231-0.888$ & $0.183-0.462$ & $0.106-0.328$ & $0.08-0.5$ \\
\hline Sulphide (mg/l) & $0.012-0.8$ & $0.024-0.32$ & $0.02-0.096$ & $0.018-0.045$ \\
\hline BOD (mg/l) & $42.6-111.8$ & $48.2-116.5$ & $32.2-78.9$ & $54.8-122.3$ \\
\hline $\begin{array}{l}\text { Total suspended } \\
\text { solids }(\mathrm{mg} / \mathrm{l})\end{array}$ & $203-229$ & $228-376$ & $224-260$ & $163-348$ \\
\hline
\end{tabular}

The present quality of effluents shows significant differences with the management practices adopted by the farmers. The water exchange rates, feeding methods, use of probiotics and use of various additives to the feed contributes to the water quality in the culture systems. (Corea 2002) Many biological, chemical and mechanical treatments are used to treat the incoming water into the culture ponds. Some have stock tanks to treat the incoming water but others treat the water while in the pond. Even during the culture cycle, ponds are treated with commercially available biological or chemical treatments to maintain water quality in the culture ponds. Some products have been successful in controlling the water quality while the action of some others are questionable. (Corea et al 2003) It was noted that some of the ponds treated with biological treatment agents had no significant difference in water quality with those not treated at all. Since the farmers expect the treated water to have better quality, the water exchange is prolonged until visually the water looks unsuitable. However, at this point the nutrient and metabolic waste concentrations are high in the pond water and therefore the effluents have a high concentration of these, 
when released. Since some farmers also add various vitamins, growth enhancers, medicines and sometimes supplementary fresh food materials including thrash fish, mollusk meat or egg; the uneaten balance of these supplementary feeds also contribute to the quality of effluents. Since most farmers have stock tanks only to treat the incoming water, the effluents are directly released into the estuarine system containing all the nutrients, chemicals, uneaten feed, and faecal matter as suspended or dissolve particles further deteriorating the quality of estuarine water. (Munasinghe et al 2010)

According to the better management practices introduced for shrimp culture, water should be treated prior to releasing to the environment. This was also a condition given to farmers while approving farms, by the approving agencies (Ministry of fisheries and Aquatic resources or the Provincial fisheries ministry) in the past before the White spot disease occurred. If the farm did not have sufficient land to develop a sedimentation area, they were requested to have a common sediment tank for a cluster of farms, or have a effluent discharge canal which should be more than $0.75 \mathrm{~km}$ in length with methods to increase sedimentation. (ie. Mangroves along canal, or barriers to slow water movement like humps) The sedimentation area recommended had been $10 \%$ of the culture area. (MOFAR 1997) However these are practiced only by a limited number of farmers even at present and even in the past only very few farmers adhered to regulations. The number of farms treating effluents and incoming water increased during the latter part of 1990's as a precaution against disease, but due to low economic returns in the industry, it was abandoned by many of them. A comparison of effluent quality in farms using Better management practices(BMP) and non BMP farms, showed there is a higher level of nutrients and toxic waste products released by the non BMP farms. (Gonapinnuwala et al 2008) This study showed a wide variation, even within BMP used farms. The farms selected for this study was from 3 culture zones using water from three different areas of the water source - Chilaw lagoon, Dutch canal Northern area and Puttalam lagoon - Mi oya estuary. The water quality in the different water bodies used as water source may have resulted in this variation. However, studies carried out later in the farms situated in the Mundel Dutch canal system showed a lesser variation in the parameters observed. Table 3 gives the comparison of the water quality in effluents from some selected BMP and non BMP farms. 
Table 3: Comparison of effluent quality in some selected BMP and non BMP farms

\begin{tabular}{lll}
\hline $\begin{array}{l}\text { Water Quality } \\
\text { Parameter }\end{array}$ & BMP effluents & Non BMP effluents \\
\hline Nitrate $(\mathrm{mg} / \mathrm{l})$ & $0.326 \pm 0.058$ & $0.34 \pm 0.049$ \\
Phosphate $(\mathrm{mg} / \mathrm{l})$ & $0.107 \pm 0.036$ & $0.152 \pm 0.018$ \\
Nitrite $(\mathrm{mg} / \mathrm{l})$ & $0.047 \pm 0.04$ & $0.027 \pm 0.008$ \\
Ammonia ( mg / $)$ & $0.035 \pm 0.012$ & $0.085 \pm 0.023$ \\
$\begin{array}{l}\text { Sulfide }(\mathrm{mg} / \mathrm{l}) \\
\begin{array}{l}\text { Total suspended solids } \\
(\mathrm{mg} / \mathrm{L})\end{array}\end{array}$ & $0.042 \pm 0.02$ & $0.048 \pm 0.022$ \\
\hline
\end{tabular}

Another factor that influence the effluent quality is the weather condition. During rainy seasons the water quality changes in the estuarine system and often some parameters are not within suitable levels for culture. Specially the salinity levels drop during rainy seasons in the estuary. Elevated nitrite levels also have been observed in the estuarine water during rainy periods, while the water discharged into the estuary through Deduru oya and Sengal oya would bring many other unsuitable chemicals washed into the system from agricultural areas, due to rains. Therefore, farmers minimize water exchange during this period. Water exchange also may be reduced during very strong drought periods. Since the salinity is elevated in the estuarine system and often the salinity and sulphide levels are elevated during dry periods, farmers minimize water exchange during dry periods too. A comparison of effluents during the different seasons is given below Table 4 .

Major problems with effluents occur during harvesting. Since the ponds are drained completely during harvesting, the effluents would contain higher concentrations of nutrients, metabolic waste products as well as organic matter. It would drain out, accumulated sludge that may contain iron, manganese, aluminium and other toxic compounds together with high concentrations of suspended solid particles. (Jayasinghe 1993) Effluent quality on the latter parts of the harvesting water is given in Table 5. The direct release of the effluents during harvesting not only contaminates the estuarine system but also cause siltation due to the heavy load of solid particles that is released with it. Effluent water during harvests also releases many other compounds to the environment and some of the contents are given in Table 6 which may not be found in high concentrations during a normal water exchange. 
At the beginning of a harvest the water that is released may be similar to the water released during a normal water exchange. But as the harvest goes on, and after the water level recedes to half the normal level, it gets mixed through the movement of shrimp restricted in less water, as well as mixing of sediments and bank erosion. Therefore, the last part of the effluents from a harvesting pond carries poorest quality water. The final $25 \%$ of water discharged would contain the highest concentrations of pollutants in the form of nutrients, sediments as well as heavy metal ions.

Table 4: Seasonal changes of effluent quality from farms using probiotic water treatments and farms not using probiotics.

\begin{tabular}{|c|c|c|c|c|}
\hline \multirow{2}{*}{$\begin{array}{l}\text { Water } \\
\text { Quality } \\
\text { Parameter }\end{array}$} & \multicolumn{2}{|c|}{ Rainy season } & \multicolumn{2}{|c|}{ Dry season } \\
\hline & $\begin{array}{l}\text { Farms using } \\
\text { probiotics }\end{array}$ & $\begin{array}{l}\text { Farms } \\
\text { without using } \\
\text { probiotics }\end{array}$ & $\begin{array}{l}\text { Farms using } \\
\text { probiotics }\end{array}$ & $\begin{array}{l}\text { Farms } \\
\text { without using } \\
\text { probiotics }\end{array}$ \\
\hline Salinity (ppt) & $07-20$ & $08-20$ & $15-45$ & $15-50$ \\
\hline $\mathrm{pH}$ & 7.6- 8.2 & 7.9- 8.5 & 7.99 .0 & $7.8-9.2$ \\
\hline $\begin{array}{l}\text { Total } \\
\text { Ammonia } \\
(\mathrm{ppm})\end{array}$ & $\begin{array}{l}0.0388- \pm \\
0.0024\end{array}$ & $\begin{array}{l}0.0343 \pm \\
0.0015\end{array}$ & $\begin{array}{l}0.0485 \pm \\
0.0065\end{array}$ & $\begin{array}{l}0.0355 \\
\pm 0.0012\end{array}$ \\
\hline Nitrite ( ppm) & $\begin{array}{l}0.0552 \\
0.0084\end{array}$ & $\begin{array}{l}0.0631 \pm 0.007 \\
7\end{array}$ & $\begin{array}{l}0.0472 \\
\pm 0.0107\end{array}$ & $\begin{array}{l}0.0315 \\
\pm 0.0058\end{array}$ \\
\hline Nitrate (ppm) & $\begin{array}{l}0.0339 \pm 0.005 \\
2\end{array}$ & $\begin{array}{l}0.0392 \pm 0.002 \\
6\end{array}$ & $\begin{array}{l}0.0425 \pm 0.007 \\
1\end{array}$ & $\begin{array}{l}0.0414 \pm \\
0.0032\end{array}$ \\
\hline $\begin{array}{l}\text { Phosphate } \\
\text { (ppm) }\end{array}$ & $\begin{array}{l}0.0321 \\
\pm 0.0059\end{array}$ & $\begin{array}{l}0.0349 \pm 0.001 \\
9\end{array}$ & $\begin{array}{l}0.0537 \pm \\
0.0074\end{array}$ & $\begin{array}{l}0.0688 \pm 0.001 \\
5\end{array}$ \\
\hline $\begin{array}{l}\text { Sulphide } \\
\text { (ppm) }\end{array}$ & $\begin{array}{l}0.469 \pm \\
0.0648\end{array}$ & $0.437 \pm 0.0263$ & $\begin{array}{l}0.323 \\
\pm 0.0498\end{array}$ & $0.289 \pm 0.0195$ \\
\hline $\begin{array}{l}\text { Total } \\
\text { suspended } \\
\text { solids (ppm) }\end{array}$ & $182.81 \pm 22.35$ & $192.5 \pm 14.26$ & $\begin{array}{l}243.75- \\
\pm 31.87\end{array}$ & $\begin{array}{l}203.13 \\
\pm 20.92\end{array}$ \\
\hline
\end{tabular}


Table 5: Effluent quality during shrimp harvest.

\begin{tabular}{lll}
\hline \multicolumn{1}{c}{ Parameter } & \multicolumn{1}{c}{$\begin{array}{c}\text { Mid harvest } \\
\text { (water reduced to half) }\end{array}$} & \multicolumn{1}{c}{$\begin{array}{c}\text { End harvest } \\
\text { (final water released } \\
\text { from pond ) }\end{array}$} \\
\hline Dissolved Oxygen $(\mathrm{mg} / \mathrm{l})$ & $2.8-3.4$ & $2.0-3.2$ \\
$\mathrm{pH}$ & $8.0-9.5$ & $8.0-9.6$ \\
Nitrite $(\mathrm{mg} / \mathrm{l})$ & $0.76-2.8$ & $1.9-3.98$ \\
Nitrate $(\mathrm{mg} / \mathrm{l})$ & $7.6-9.9$ & $8.2-16.8$ \\
Ammonia $(\mathrm{mg} / \mathrm{l})$ & $0.67-2.4$ & $1.2->3.0$ \\
Phosphate $(\mathrm{mg} / \mathrm{l})$ & $4.1-6.3$ & $5.2-9.9$ \\
Sulphide $(\mathrm{mg} / \mathrm{l})$ & $0.52-1.90$ & $2.2-3.5$ \\
Suspended solids $(\mathrm{mg} / \mathrm{l})$ & $384.2-648.7$ & $840.7-1232.9$ \\
\hline
\end{tabular}

Table 6: Some of the contaminants found in the effluent discharged during the end of the harvest

\begin{tabular}{ll}
\hline Parameter & Concentration \\
\hline Iron - Fe (mg/l) & $12.6-18.9$ \\
Manganese - Mn (mg/l) & $1.3-2.1$ \\
Aluminium - Al (mg/l) & $2.1-2.4$ \\
Zinc - Zn (mg/l) & $0.09-0.16$ \\
Lead - Pb (mg/l) & $0.010-0.014$ \\
Chromium - Cr (mg/l) & $0.5-1.8$ \\
\hline
\end{tabular}

Microbiological quality in the effluents also change seasonally as well as with the management practice. Table 7 gives some information on the total bacteria and Vibrio counts in effluents during rainy and dry seasons. High vibrio counts indicate poor water quality as most pathogenic bacteria fall into this category. 
Table 7: Seasonal changes in bacterial counts in water with different management practices

\begin{tabular}{llccc}
\hline & \multicolumn{2}{c}{ Rainy season } & \multicolumn{2}{c}{ Dry season } \\
\cline { 2 - 5 } & With probiotics & $\begin{array}{c}\text { Without } \\
\text { probiotics }\end{array}$ & With probiotics & $\begin{array}{c}\text { Without } \\
\text { probiotics }\end{array}$ \\
\hline $\begin{array}{l}\text { Total bacteria } \\
\text { cfu/ml }\end{array}$ & $162-207 \times 10^{3}$ & $99-264 \times 10^{3}$ & $91-150 \times 10^{3}$ & $49-293 \times 10^{3}$ \\
$\begin{array}{l}\text { Total Vibryo } \\
\text { cfu/ml }\end{array}$ & $0-5 \times 10^{3}$ & $0-18 \times 10^{3}$ & $0-11 \times 10^{2}$ & $2-61 \times 10^{2}$ \\
\hline
\end{tabular}

\section{Required conditions for shrimp culture.}

For any aquatic organism including shrimp there are acceptable limits of water quality supporting their growth. If the water is of poor quality, it could cause stress to shrimp and they would be susceptible to disease. Poor water quality results in many bacterial fungal and other parasitic infections in cultured shrimp. The stress could also lead to the emergence of viral infections which may otherwise be controlled due to good culture environment. The suitable water quality levels for shrimp culture and other estuarine fauna is given in Table 8. (Boyd 1989, Poernomo1990 Jayasinghe et al, 1993a, and Jayasinghe et al, 2000,) These are generally acceptable for most brackish water fauna and therefore the conditions should apply for the estuarine systems water quality too. Since most natural occurring species are adapted to the natural conditions of the water body they live in, they are capable of adjusting themselves to changes in the water quality up to a certain extent. But permanent changes may reduce the biodiversity in the lagoon as the organisms may not tolerate such changes for long periods.

The present condition in the estuarine system does not meet the standards favourable for aquatic life or shrimp culture with respect to some parameters, due to contamination of the lagoon water by the farm effluents which loads nutrients, metabolic waste and the suspended particles. Most of these substances settle in the lagoon and continues to keep the water quality at unfavourable levels for aquatic fauna, until it is diluted or flushed out by rains or is decomposed. This problem also varies seasonally as some parameters improve with the rains while others improve with the drought. Specially levels of nitrite, sulphide etc. improve with the drought while levels of nutrients, and suspended particles improve with the rainy season when flushing is facilitated. However, the stress during both seasons could lead to disease outbreaks. The intake water from the lagoon therefore contains unsuitable quality for 
shrimp culture purposes and needs treatment prior to use. If untreated water is used it is further deteriorated within the culture ponds, due to excess feed and faecal matter accumulation. This may result in disease conditions or retarded growth in shrimp. Therefore, the effluents which are released, contains much degraded water and the natural system in the lagoon is not capable of completely upgrading the water quality to suit aquatic life. Since the volume of water received by the estuarine system from farm discharge, is greater than the volume available in the canal in some areas natural water purification of the canal may not be able to handle these large volumes daily. Therefore, introduction of better management practices to control water quality is considered essential in farms and some standards need to be introduced to the effluents which are released to the system.

Table 8: Suitable ranges of water quality for shrimp culture and brackish water aquatic fauna

\begin{tabular}{lcc}
\hline Water Quality Parameter & Shrimp culture & General Aquatic fauna \\
\hline Temperature & $25-30$ & $26-33$ \\
Salinity & $10-35$ & $5-35$ \\
Turbidity & $20-30$ & $3-12$ \\
Dissolved Oxygen & $4.0-7.0$ & .4 .0 \\
pH & $7.5-8.7$ & $7.5-8.7$ \\
Total ammonia & $<0.1$ & $<0.25$ \\
Nitrate & $<10.0$ & $<100$ \\
Sulphide & $<0.1$ & $<0.25$ \\
Nitrite & $<0.25$ & $<0.25$ \\
BOD & - & $<10$ \\
Total suspended solids & - & $<20$ \\
\hline
\end{tabular}

The bacterial quality also plays a major role in the quality of water. Yet it is reflected only in a few articles. The bacterial loadings can cause stress in aquatic fauna rendering susceptible to opportunistic bacterial diseases. High total bacterial counts have been observed prior to white spot disease in shrimp ponds. (Ariyawansa et al.1998) This also indicates that high bacterial loads could lead to stress and to various diseases. 


\section{Standards for aquaculture effluents.}

Aquatic animals perform all its physiological activities in water - breathing, excretion of waste, feeding, maintaining salt balance and reproduction. Hence, water quality is the determining factor on the success or failure of an aquaculture operation. If the aquatic environment is ideal for shrimp, they will grow fast and would be less susceptible to disease. In the same way, if the surrounding aquatic environment is clean and suitable for aquatic life, the natural production in the estuarine system would be high. Anyhow fisher folk have been complaining that, the fishery production is dwindling due to the pollution in the estuarine system, caused by the shrimp farm effluents.

The need for standards for the aquaculture effluents was felt during the early periods of the industry, as the effluents were disposed into the natural ecosystem of MundelPuttalam estuary commenced to change the estuarine water quality. With the first disease outbreak in the shrimp industry in 1989, where the spread of the disease was attributed to poor water quality used for culture purposes, the need for better water quality was felt by the industry itself. After the disease was controlled, this was forgotten when the industry started to expand. Consequently, the Central Environmental Authority proposed having standards for effluents as a measure of protecting the surrounding ecosystem.

The CEA has introduced standards for general effluent quality and industrial waste water disposal to the natural systems. They also proposed the standards for effluent quality from aquaculture practices in 1990. (Table 9) Anyhow this was not implemented and only the standards proposed for industrial waste water and general water quality were implemented. (CEA, 1990) Presently the standards stipulated for the above is adopted for aquaculture too. But these standards do not meet the needs of the aquaculture industry or the water quality suitable for many brackish water organisms. It is expected that the released pollutants would get diluted in the natural system. In the case of Sri Lankan aquaculture, the effluents released to the environment remain for a long period, because there is hardly any mixing to dilute it. 
Table 9: Proposed effluent discharge quality standards by CEA in 1990

\begin{tabular}{lcc}
\hline \multicolumn{1}{c}{ Parameter } & To Inland surface waters & $\begin{array}{c}\text { To marine and coastal } \\
\text { waters }\end{array}$ \\
\hline BOD $(5 \mathrm{~d})(\mathrm{mg} / \mathrm{l})$ & 30 & 50 \\
COD $(\mathrm{mg} / \mathrm{L})$ & 250 & 250 \\
$\mathrm{pH}$ & $6.0-8.5$ & $6.0-8.5$ \\
Suspended solids $(\mathrm{mg} / \mathrm{l})$ & 50 & 100 \\
Temperature $\left({ }^{\circ} \mathrm{C}\right)(\mathrm{mg} / \mathrm{l})$ & 30 & 35 \\
Oil and Grease $(\mathrm{mg} / \mathrm{l})$ & 10 & 20 \\
Total nitrogen $(\mathrm{mg} / \mathrm{l})$ & 2.0 & 2.0 \\
Phosphate $(\mathrm{mg} / \mathrm{l})$ & 2.0 & 2.0 \\
Phenolic compounds $(\mathrm{mg} / \mathrm{l})$ & 1.0 & 5.0 \\
Cyanides $(\mathrm{mg} / \mathrm{l})$ & 0.2 & 0.2 \\
Sulphides $(\mathrm{mg} / \mathrm{l})$ & 2.0 & 5.0 \\
Fluorides $(\mathrm{mg} / \mathrm{l})$ & 2.0 & 15.0 \\
Total residual chlorine $(\mathrm{mg} / \mathrm{l})$ & 1.0 & 1.0 \\
Arsenic $(\mathrm{mg} / \mathrm{l})$ & 0.1. & 0.2 \\
Cadmium $(\mathrm{mg} / \mathrm{l})$ & 0.1 & 2.0 \\
Chromium (mg/l) & 3.0 & 1.0 \\
Copper $(\mathrm{mg} / \mathrm{l})$ & 0.0005 & 3.0 \\
Lead $(\mathrm{mg} / \mathrm{l})$ & & 0.0 \\
\hline
\end{tabular}

Another problem is that the effluents are released to the same water body that act as the water source for aquaculture, thereby resulting in other farms obtaining the contaminated water. The guidelines for industrial waste water has considered only the pollutants found commonly in the effluents of other industries. However, aquaculture waste water is different from most other industries as the inputs are different. Therefore, the guidelines for aquaculture effluents should include the parameters that are directly related to the industry as it deals with live organisms.

Among the parameters considered by the CEA many heavy metals and toxic ions have been included. The use of these heavy metals in aquaculture is minimal due to its ability to persist in body tissue of the cultured animals, and could result in rejection 
of the product in the export market. The quantities of these released to the water through aquaculture effluents is much less than the stipulated standards, and may be added in minute amounts, as feed, chemical treatments or from the soil due to erosion of bunds. Many pesticides are used in water treatment during disease periods and some times during pond preparation, to eradicate unwanted aquatic fauna from the culture area. (Munasinghe et al 2010) These could contain toxic substances to other aquatic life. There is no monitoring of the water released into the environment after the use of chemicals, although by regulation the water has to be stored within the farm, until the effect of the pesticide is worn off. Since some farms release water in a short period after treatment, the active ingredients may not have degraded prior to releasing the water, which, may then cause mortality of aquatic fauna in the lagoons.

Standards for aquaculture effluents have been a concern in many countries during the recent years. Specially shrimp farm effluents have received attention for environmental pollution worldwide (Barraza-Guardado et al 2013, Páez-Osuna et al 1998) Standards have been proposed for aquaculture pollution control in other parts of the world too. (PHILMINAQ) India has introduced such standards and it is being implemented presently. (CAA India 2005) USA has not proposed definite standards for aquaculture but has stipulated that effluent quality should be maintained through better management practices. The effluent quality and the need for standards for aquaculture is still being considered, as different culture species, need different sets of standards. (Summerfelt, 2003). Several papers on improving effluent quality has been presented so that effluents would be of a suitable quality when released to the environment, without causing problems to organisms living in surrounding water bodies, or to humans. (Ramos et al 2009, Songsangjinda 2004) In Texas the permit issued to farms for aquaculture stipulates the minimum and maximum levels of pollutants that can be released to the environment, with guidelines for better management practices that would help accomplish this. (Samocha \& Lawrence) Other parts of US, have provided methods for improving effluent quality. (Boyd 2000, 2003) Following the guidelines would improve effluent quality before release. The effluents from a pond being harvested need to go through a settlement pond. Since the highest concentrations of particulate matter is released with the final $25 \%$ of the water drained from the pond, this effluent should be kept for 48 hours in the settling pond before release. But if the suspended particle concentration is less than 30mg/l it can be directly released. (Teichert-Coddington1999) However this type of solution needs continuous monitoring. Indian regulations imply that antibiotic and chemical residues will also be monitored. Antibiotics and pesticides are used without proper guidance in aquaculture farms at present. (Munasinghe et al 2010) For this reason, monitoring these may be a necessity. Most farms producing edible species 
such as shrimp for export, do not use chemicals and antibiotics as regulations would not permit exporting their product.

Considering the formerly proposed standards by the CEA and the present conditions in the estuarine system with the water quality needed for aquatic life, the following standards could be proposed for the effluents from shrimp farms (Table 10) The parameters considered are those that have been identified from the shrimp ponds in high concentrations. This has also considered the present stress conditions which lead to shrimp disease and conditions recorded from the lagoon as detrimental to organisms living in the estuarine system. The standards proposed by many other countries are similar to the standards recommended in this paper.

Table 10: Recommended and proposed standards for Aquaculture effluents.

\begin{tabular}{lc}
\hline Parameter & Recommended standards for effluents. \\
\hline Temperature & $<35^{\circ} \mathrm{C}$ \\
Turbidity & $<50 \mathrm{Ntu}$ \\
Dissolved Oxygen & $>4.0 \mathrm{mg} / \mathrm{l}$ \\
$\mathrm{pH}$ & $7.5-8.5$ \\
Total ammonia & $<2.0 \mathrm{mg} / 1$ \\
Unionized ammonia & $<0.5 \mathrm{mg} / 1$ \\
Nitrate & $<10 \mathrm{mg} / 1$ \\
Nitrite & $<1.0 \mathrm{mg} / 1$ \\
Phosphate & $<1.0 \mathrm{mg} / 1$ \\
Sulphide & $<0.2 \mathrm{mg} / 1$ \\
BOD (5days) & $<50$ \\
Total suspended solids & $<100 \mathrm{mg} / \mathrm{l}$ \\
COD & $<100$ \\
\hline
\end{tabular}

The farmers could be requested to treat the effluents prior to discharging as this was a requirement earlier when farms were licensed by the Central Ministry of Fisheries or the Provincial fisheries ministry. The recommended treatment method was sedimentation and aeration. After all, the treatment facility could be a sediment tank, or an elongated effluent canal with barriers to break the water speed and facilitate sedimentation. The treatment facility could also utilize biological agents to purify the water. Recommended species would be mangrove plants, to filter suspended particles 
and nutrients, filter feeders such as fish species (milk fish or Tilapia), mollusk species and sea weeds or sea grass species to reduce the nutrient levels. (Jayasinghe 1998) The accumulated organic sediments in the treatment area also could be reduced by using detritus feeders or sediment filtering mollusks. Further the use of probiotic bacteria which could convert toxic nitrites, ammonia and other chemical substances to less toxic forms could help in improving the water quality. (Corea et al 2005)) It would reduce the chance for algal blooms or toxic algal growth in the estuarine system triggered by the high nutrient levels received by the estuarine system. Polyculture methods also have been successful in reducing total nitrogen and suspended particulate matter from effluents. (Araújo-Silva et al. 2014) Several methods have been suggested in other countries to reduce the waste loadings. Thailand treats waste water using constructed wetlands and has also recommended use of probiotics to maintain water quality. (Sansanayuth et al 1996, Agricultural standards 2011) Treatment of shrimp effluents using sedimentation, oyster filtration and macro-algal absorption to meet the standards as well as using omnivorous fin fish (Siganus nebulosus), mullet (Mugil cephalus) together with Enteromorpha spp has also been suggested. (Erler etal 2004, Jones et al 2001,)

Recommendations to reduce bacterial loadings also would be necessary. Despite this, further studies are needed before recommending a standard for bacterial levels and suggest methods for reducing bacteria in the effluents. Since disease causing bacteria, as well as beneficial bacteria which help in regulating environmental balance, add up to the total bacterial counts, total bacteria is not a suitable measure of bacterial quality. Usually most shrimp diseases are caused by Vibrio species. (Lavilla-Pitogo 1998, Heenatigala et al, 2012) However there are non-disease causing Vibrio as well found in the aquatic environment. Therefore, the Vibrio counts also would not be a correct measure of pollution. All the same high vibrio counts would indicate deteriorated water.

Control of water quality usually improves the bacteria quality as well. More beneficial and non-harmful bacteria are found in better quality water while the harmful species thrive well in poor quality water. Water filtering organisms like mollusk species would filter the bacteria as well, while, use of some probiotic and prebiotic applications with beneficial bacteria would help to maintain bacterial quality. (Qunlan et al 2009) Increasing the numbers of beneficial bacteria would control and reduce the numbers of harmful bacteria. Sometimes providing organic matter (sugar or molasses) for improving beneficial bacteria, would improve bacterial quality as well as water quality. Using bioflocs in aquaculture is based on combinations of organic matter and microbiota. (Gaona et al 2011) Biofloc technology in aquaculture are based on activated-sludge wastewater treatment systems and it helps preventing disease in cultured species as well. 
In Sri Lanka since the use of antibiotics is banned monitoring for residues is carried out only for shrimp that are exported. Since shrimp containing antibiotic residues will be rejected from export it is expected that farmers will refrain from using these in the culture ponds. On the other hand, regulations on use of other chemicals are not monitored this way. It could be recommended that if any other chemical is used, the water should not be released to the environment for a period of at least 72 hours or until the effect of such chemicals have been degraded. It should be suggested that if pesticides are used to kill fish or any other organisms in the ponds, special care should be taken to keep the water stored until its effective period is past, so that release of such water, would not affect the estuarine organisms.

\section{Conclusion}

Standards for shrimp culture is a timely need for the sustainability of the industry in Sri Lanka as the direct discharge of effluents have degraded the water quality in the estuarine system. Monitoring of effluents would make sure that it is not limited to legislation. Therefore, it is recommended that these standards should be adopted to regulate the release of untreated effluents to the environment from shrimp farms so that the estuarine system would be able to support better aquatic biodiversity. Therefore, to preserve the system in good condition some legislation on effluent discharge is needed.

\section{Reference}

Agricultural standards (2011) Good aquaculture practices for marine bio-shrimp farm- National Bureau of Agricultural Commodity and Food Standards Ministry of Agriculture and Cooperatives Thailand

Araújo-Silva, S., Moraes, M., Carmo, C., Osti, J., Vaz-Dos-Santos, A. and Mercante, C. (2014) Effluent of a Polyculture System (Tilapias and Shrimps): Assessment by Mass Balance of Nitrogen and Phosphorus. Journal of Environmental Protection, 5, 797-802. doi: 10.4236/jep.2014.510081.

Ariyawansa K.W.S, J.M.P.K. Jayasinghe and K.S. Hettiarachchi (1998), Bacterial profiles in shrimp culture systems affected by white spot epizootic. - Sri Lanka Journal of Animal Production. 1(1):61-68.

Arulananthan, K (2005), 'Anthropogenic Effects on the Dynamics of Coastal Ecosystems in Sri Lanka'; Proceedings of the International Workshop on Fisheries and Aquatic Research in Sri Lanka, National Aquatic Research Development Agency, Colombo 15, Sri Lanka. 
Asian development bank (1990), Sri Lanka appraisal reporton present disease situation in prawn farms in Sri Lanka; Ministry of Fisheries and Aquatic resources Colombo

Barraza-Guardado, R. H., Arreola-Lizárraga, J. A., López-Torres, M. A., CasillasHernández, R., Miranda-Baeza, A., Magallón-Barrajas, F., \& Ibarra-Gámez, C. (2013). Effluents of Shrimp Farms and Its Influence on the Coastal Ecosystems of Bahía de Kino, Mexico. The Scientific World Journal, 2013, 306370 .

(Available at http://doi.org/10.1155/2013/306370 [Accessed 15th May 2017])

Boyd C E (1989), Water quality management and aeration in shrimp farming (Feb 1989) Fisheries and allied aquaculture department series no 2 Aubern university Alabama 79pp

Boyd C.E. (2000) Effluent Composition and water quality standards; limits for GAA effluent standards- Implementing GAA's Responsible Aquaculture Program; THE ADVOCATE October 2000:61 - 66

Boyd Claude E. (2003) Guidelines for aquaculture effluent management at the farmlevel; Aquaculture 226 (2003) $101-112$

Central Environment Authority (1990) Draft standards for effluents released to coastal and inland water bodies. CEA Sri Lanka

Coastal Aquaculture Authority India (2005) Guidelines for regulating coastal aquaculture -Guidelines annexed to Coastal Aquaculture Authority Rules,

Available at http//www. Indiacaa.gov.in/uploaded/doc/Guidelines-Englishnew.pdf [Accessed 15th May 2017]

Corea A.S.L.E., Jayasinghe J.M.P.K. and Ekaratne S.U.K. (1993), Effects of water quality of shrimp farm effluents on brackish water bodies of the North Western province of Sri Lanka. - Proceedings of 1993Annual sessions of National Aquatic Resources Agency

Corea A. S. L. E. (1995) Environment impact of prawn farming on Dutch canal the main water source for the prawn culture industry in Sri Lanka423 427 Ambio $7-8$

Corea A.S.L.E., Wijesekara R.G.S. and Jayasinghe J.M.P.K. (1997), SEMBV outbreak in Sri Lanka: What went wrong? - Proceedings of 3rd Annual sessions of the Sri Lanka Association for Fisheries and Aquatic Resources (SLAFAR), Sri Lanka. 
Corea A. S. L. E. (1998) Self-pollution: A major threat to the prawn farming industry in Sri Lanka Ambio, 27(8), 662 - 668.

Corea A.S.L.E. and Jayasinghe J.M.P.K. (2002) Mitigation of adverse impacts of shrimp culture development on the coastal areas of North western province of Sri Lanka. - Sida/ SAREC regional workshop on Relating the environment to Development. Colombo Sri Lanka

Corea A.S.L.E. and Jayasinghe J.M.P.K. (2003) Impact of commonly used epibiotics on the water quality in shrimp grow out ponds bordering the Dutch canal Mundel lagoon, Sri Lanka, - Asian-Pacific Aquaculture 2003 - September 2225, 2003, Bangkok, Thailand

Corea A.S.L.E., J.M.P. K. Jayasinghe (2005) Use of biological treatment methods to treat shrimp farm effluents - International workshop on Fisheries and Aquatic research in Sri Lanka, NARA Colombo 15, Sri Lanka.

Corea, A.S.L.E., (2007), Recent trends in shrimp farm performance and culture environment with special reference to shrimp health. - International workshop on Tropical aquatic research - NARA Colombo 15, Sri Lanka.

Corea A.S.L.E. (2009) Trends in water quality changes in main water source for shrimp culture and the need for standards for shrimp farm effluents. Proceedings of 15th Annual sessions of the Sri Lanka Association for Fisheries and Aquatic Resources (SLAFAR), Sri Lanka

Dayaratne, P., Linden, O., and De Silva, M. W. R. (Eds.). (1997). The Puttalam/Mundel Estuarine Systems and Associated Coastal Waters. A report on environmental degradation, resource management issues and options for their solution. Colombo:NARA and NARESA. 98 pp.

Erler Dirk, Peter Pollard, Peter Duncan, Wayne Knibb (2004) Treatment of shrimp farm effluent with omnivorous finfish and artificial substrates, - Aquaculture research 35, (9) :816-827: DOI: 10.1111/j.1365-2109.2004. 01019.x

Gonapinuwala, S. T, Jayasinghe, J. M. P. K., Jayakody, D. S and Kariyawasam, M. I (2008) Assessment of bacterial loadings from shrimp farm under Better Management Practices: Proceedings.Sri Lanka Association for Fisheries and Aquatic Resources. (14):12

Gaona, C. A. P., L. H. Poersch, D. Krummenauer, G. K. Foes, and W. Wasielesky. 2011. The effect of solids removal on water quality, growth and survival of Litopenaeus vannamei in a biofloc technology culture system. International Journal of Recirculating Aquaculture 12:54-73 
Heenatigala P P M (2012). Species Diversity and Antibiotic Sensitivity of Pathogenic Bacteria Associated with Hatchery Bred Shrimp Larvae in Sri Lanka. Proceedings of international workshop of World Aquaculture Society, Aqua 2012, Prague, Czech Republic. p. 109

Jayasiri H.B. (1997) seasonal water exchange evaporate deposit of salt and salinity variations in the Mundel lake a coastal lagoon in Sri Lanka M Phil thesis Department of Oceanography Gotenboerg university, Sweden

Jayasinghe J. M. P. K. and Mackintosh D.J. (1993a) Disease out-breaks in the shrimp culture grow-out systems of Sri Lanka. Journal of Tropical Agricultural Research. (5): 336 -349

Jayasinghe, JMPK (1993 b), 'Shrimp Culture in Sri Lanka; Immediate Profits or Sustainable Development', Annual Scientific Session, NARA, Crow Island, Colombo 15, Sri Lanka.

Jayaisnghe, J.M.P.K., S.C. Corea and P.K.M. Wijegoonawardena (1994). Deterioration of sanitation in the coastal water bodies of North Western Province of Sir Lanka. Effects of unplanned Development in shrimp culture industry.Proc. conference on Affordable water supply and sanitation. Aug. 22 - 26, 1994. Sri Lanka.

Jayasinghe, J.M.P. K (1998) Water management options for shrimp culture in Sri Lanka 1990: National aquatic resources Agency Sri Lanka. pp 32

Jayasinghe J.M.P.K., and Wijesekara.R.G.S (2000), Technical and Social Aspects in Brackish Water Shrimp Culture (Sinhala medium), ISBN-955-8014-01-X, National Aquatic Resources Research and Development Agency, Colombo Sri Lanka.

Jones A.B, W.C. Dennison N.P. Preston (2001) Integrated treatment of shrimp effluent by sedimentation, oyster filtration and macroalgal absorption: a laboratory scale study: Aquaculture 193 (1-2): 155-178

Lavilla-Pitogo, C. R., \& de la Peña, L. D. (1998). Bacterial diseases in shrimp (Penaeus monodon) culture in the Philippines. Fish Pathology, 33(4): 405-411.

(MOFAR) Ministry of Fisheries and Aquatic Resources (1997) Report on rehabilitation of shrimp farms Ministry of Fisheries and Aquatic Resources Colombo

Munasinghe M. Nalaka, Craig Stephen, Preeni Abeynayake, and Indra S. Abeygunawardena,(2010) "Shrimp Farming Practices in the Puttallam District of Sri Lanka: Implications for Disease Control, Industry Sustainability, and 
Rural Development," Veterinary Medicine International, vol. 2010, Article ID 679130, 7 pages, 2010. - doi:10.4061/2010/679130

NARA (1987) survey of potential areas for prawn culture phase 1 National Aquatic Resources Agency Colombo 260pp

Páez-Osuna Federico, Saúl R Guerrero-Galván, Ana C Ruiz-Fernández,( 1998,)The environmental impact of shrimp aquaculture and the coastal pollution in Mexico, Marine Pollution Bulletin,36, (1): 65-75,

PHILMINAQ, "Water Quality Criteria and Standards for Freshwater and Marine Aquaculture," [Online]. . [Accessed 15th May 2017]

Available: http://aquaculture.asia/files/PMNQ\%20WQ\%20standard\%202.pdf

Poernomo A.T. (1990), Site selection for coastal prawn ponds - proceedings Aquatec conference, New N B and Saram H (ed)Malasia p3-19

Phillips M. J. (1995). Shrimp culture and the environment. In T. U. Bagarinao \& E. E. C. Flores (Eds.), Towards Sustainable Aquaculture in Southeast Asia and Japan: Proceedings of the Seminar-Workshop on Aquaculture Development in Southeast Asia, Iloilo City, Philippines, 1994 (pp. 37-62).

Ramos, Roberto, Vinatea, Luis, Seiffert, Walter, Beltrame, Elpídio, Silva, Júlia Santos, \& Costa, Rejane Helena Ribeiro da. (2009). Treatment of shrimp effluent by sedimentation and oyster filtration using Crassostrea gigas and $C$. rhizophorae. Brazilian Archives of Biology and Technology, 52(3), 775-783. https://dx.doi.org/10.1590/S1516-89132009000300030

Samocha, T.M., and A.L. Lawrence. (1997), Shrimp farms effluent water, environmental impact and potential treatment methods. Pages 33-57 in B.J. Keller, P.K. Park, J.P. McVey, K. Takayanagi and K. Hosoya, eds. Water Effluent and Quality, with Special Emphasis on Finfish and Shrimp Aquaculture. Proceedings of the 24th US-Japan Aquaculture Panel $\begin{array}{llll}\text { Symposium. UJNR Nechnical } & \text { Report }\end{array}$ www.nsgl.gso.uri.edu/tamu/tamuw95003/tamuw95003_part3a.pdf [Accessed 15th May 2017]

Sansanayuth P., Phadungchep A., Ngammontha S., Ngdngam S., Sukasem p., Hoshino H., Ttabucanon M.S., (1996) Shrimp pond effluent: pollution problems and treatment by constructed wetlands: water science and Technology 34 (11): 93-98

Songsangjinda, P. (2004). Integrated physical and biological technologies for water recycling in shrimp farms. In: Promotion of mangrove-friendly shrimp 
aquaculture in Southeast Asia (pp. 36-49). Tigbauan, Iloilo, Philippines: Aquaculture Department, Southeast Asian Fisheries Development Centre

Sureshkumar N. (1998) Nutrient and metabolic loading from shrimp ponds to environment. M.Phil. thesis Dept. of Zoology, University of Colombo

Summerfelt Robert C. (2003) Introduction to "Aquaculture Effluents: overview of EPA guidelines and standards and BMPs for ponds, raceways, and recycle systems "-Natural Resources Ecology and Management conference papers; [Accessed 15th May 2017] Available at http://lib.dr.iastate.edu/cgi/viewcontent.cgi?article $=1016 \&$ context=nrem_cof

Teichert-Coddington D.R., D.B. Rouse, A. Potts, C.E. Boyd (1999) Treatment of harvest discharge from intensive shrimp ponds by settling; - Aqua-cultural Engineering 19: 147-161

Qunlan Zhou, Kangmin Li, Xie Jun, Liu Bo (2009) Role and functions of beneficial microorganisms in sustainable aquaculture - Bio-resource Technology 100: $3780-3786$

Wijeratne E.M.S., J.K.Rajapakse, ULF Cederlof (1996) Tidal response of different types of lagoons on the west coast of Sri Lanka; Regional workshop for the management of coastal resources in the tropics, National Aquatic Resources Research and Development Agency Sri Lanka 